Indian Journal of Science and Technology

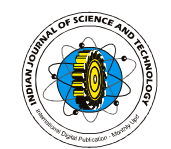

\title{
KAP on Malaria - a brief account of responses of newly joined medical undergraduates
} of SDMCMS \& H, Dharwad, India

\author{
Lata Radhakrishna Kollur*, Shivani Manjrekar and J.V.Chowti \\ Department of Community Medicine, SDMCMS \& H, Dharwad-580009, India \\ *kollurl@yahoo.com
}

\begin{abstract}
Malaria is a major public health problem in India. A cross-sectional study has been conducted on newly joined medical undergraduates of SDMCMS\&H using pre-tested, pre-designed questionnaire to assess Knowledge, Attitude, Practices (KAP) regarding malaria. Handouts were distributed followed by health education. Data was analyzed using descriptive statistics. Out of 95 students, $89(93.6 \%)$ reported malaria to be a serious disease if not treated in time and $93(97.8 \%)$ knew that malaria transmission occurs by mosquito bite, Mosquito responsible is female anopheles (96.8\%) and dirty stagnant water reported as breeding site by $90(94.7 \%)$ students and Plasmodium as the malaria parasite was known to $71(74.7 \%)$. Among the reported symptoms of malaria, fever was the most common answer. Investigation to diagnose malaria is blood test according to $78(82.1 \%)$. Using coil or repellants in house protects from mosquito bite according to $65(68.4 \%)$. Insecticide treated bed nets and indoor residual spraying were known to 19 $(20 \%)$ and 32 (33.6\%) students respectively.52 (54.7\%) students were aware of Governmental measures. Knowledge regarding insecticide treated bed nets; Indoor residual spraying was comparatively less. Not many knew about rapid diagnostic test (RDT).
\end{abstract}

Keywords: Indoor residual spraying, Insecticide treated bed nets, Mosquito.

\section{Introduction}

Malaria continues to pose a major public health threat in Indian (Park, 2011). It not only poses high risk to health of the individual but also places burden on households, health services and ultimately on economic growth of communities and nation. The mosquito-borne diseases result in avoidable ill-health and death which also has been emphasized in National Health Policy (Park, 2009).

Government of India is working on the control of mosquito transmitted diseases. The National malaria control programme was launched in 1953; it has been renamed as National anti-malaria programme in 1999. In 2003, renaming of NAMP to National Vector Borne Disease Control Programme was done (Park, 2011).

The present study was designed with following objectives: a) To assess the knowledge, attitude and practices of newly joined medical undergraduates of SDMCMS \& $\mathrm{H}$, about malaria and b) To sensitize the students to available measures for prevention and cure of malaria.

\section{Material and methods}

Study design: Cross-sectional study; Study area: SDMCMS \& H, Dharwad; Study participants: Newly joined undergraduate medical students; Inclusion criteria: All students present on the day of study; Exclusion criteria: Students absent on the day of study; Study instrument: Pretested questionnaire in English; Statistical analysis: Descriptive statistics was performed.

A cross-sectional study was carried out to assess the knowledge, attitude, practices among newly joined undergraduate medical students of SDMCMS \& $\mathrm{H}$, Dharwad, about malaria. Students present on the day of study were included. Informed written consent to participate in the study was taken from each participant and confidentiality was maintained.

Popular article

(C)Indian Society for Education and Environment (iSee)
A pre-tested, pre-designed questionnaire forms for filling the responses were distributed. The filled forms were collected. This was followed by distribution of handouts and health education on preventive and curative aspect of malaria. Depending upon the responses obtained, the data was analyzed to know knowledge, attitude and practices of students regarding malaria using frequency distribution and percentages.

Results

The results are presented in Table (1-6) and out of 100 students, 95 participated in the study remaining 5 students were absent. 41 (43.1\%) responded that they themselves or any one known to them have suffered from malaria. Awareness about insecticide, treated bed nets and indoor residual spraying was present in $19(20 \%)$ and $32(33.6 \%)$ students respectively. When asked regarding lifelong immunity provided by one attack of malaria, 21 $(22.1 \%)$ responded in positive way. Availability of malaria vaccines was known to $55(57.8 \%)$ students.

\section{Discussion}

In the present study, according to 89 (93.6\%) students, malaria could be a serious disease if not treated in time and $93(97.8 \%)$ students had knowledge about malaria being transmitted by mosquito bite; $92(96.8 \%)$ students responded female anopheles mosquito to be responsible for malaria transmission.

In a study on community knowledge, attitude and practice on malaria in Swaziland by Hlongwana et al. (2009), showed that out of 320 households surveyed by them, $298(93.1 \%)$ of the respondents had heard about malaria and almost all, that is $297(99.7 \%)$ correctly associated malaria with mosquito bite and also demonstrated appropriate knowledge of an attitude towards malaria by stating that it could kill if not treated. In another study in
"KAP on malaria"

http://www.indjst.org
L.R.Kollur et al. Indian J.Sci.Technol. 
Table1. Knowledge about malaria disease among newly joined undergraduate medical students.

\begin{tabular}{|c|c|c|}
\hline \multirow[t]{2}{*}{ Queries } & \multicolumn{2}{|c|}{ Response } \\
\hline & No. & $(\%)$ \\
\hline $\begin{array}{l}\text { Q1.According to you malaria is a/an } \\
\text { a. Ordinary disease } \\
\text { b. Serious disease if not treated in time } \\
\text { c. A serious disease }\end{array}$ & $\begin{array}{l}3 \\
89 \\
5\end{array}$ & $\begin{array}{l}3.15 \\
93.6 \\
5.2\end{array}$ \\
\hline $\begin{array}{l}\text { Q2.Name of malaria vector } \\
\text { a. Female Anopheles } \\
\text { b. Male Anopheles } \\
\text { c. Male Culex } \\
\text { d. Aedes mosquito }\end{array}$ & $\begin{array}{l}92 \\
2 \\
0 \\
1\end{array}$ & $\begin{array}{l}96.8 \\
2.1 \\
0 \\
1.05\end{array}$ \\
\hline $\begin{array}{l}\text { Q3.Malaria vector breeds in } \\
\text { a. Dirty stagnant water } \\
\text { b. Clean stagnant water } \\
\text { c. Dirty flowing water } \\
\text { d. Clean flowing water }\end{array}$ & $\begin{array}{l}90 \\
5 \\
0 \\
0\end{array}$ & $\begin{array}{l}94.7 \\
5.26 \\
0 \\
0\end{array}$ \\
\hline $\begin{array}{l}\text { Q4. Malaria parasite belongs to } \\
\text { a. Bacteria } \\
\text { b. Protozoa (Plasmodium) } \\
\text { c. Virus } \\
\text { d. Amoeba }\end{array}$ & $\begin{array}{l}9 \\
71 \\
11 \\
0\end{array}$ & $\begin{array}{l}9.47 \\
74.7 \\
11.5 \\
0\end{array}$ \\
\hline $\begin{array}{l}\text { Q5. When infected with malaria you } \\
\text { consulted to } \\
\text { a. Govt. hospital } \\
\text { b. Private hospital } \\
\text { c. Traditional healer } \\
\text { d. Home remedies } \\
\text { e. Did nothing }\end{array}$ & $\begin{array}{l}6 \\
34 \\
1 \\
0 \\
0\end{array}$ & $\begin{array}{l}14.6 \\
82.9 \\
2.4 \\
0 \\
0\end{array}$ \\
\hline $\begin{array}{l}\text { Q6. Do you know the name of } \\
\text { some of the commonest } \\
\text { medicines used in malaria? } \\
\text { a. Chloroquine } \\
\text { b. Quinine } \\
\text { c. Other medicine } \\
\text { d. No idea }\end{array}$ & $\begin{array}{l}46 \\
45 \\
10 \\
14\end{array}$ & $\begin{array}{l}48.4 \\
47.3 \\
10.5 \\
14.7\end{array}$ \\
\hline $\begin{array}{l}\text { Q7.Do you know the name } \\
\text { of some commonly used insecticides for } \\
\text { mosquito control? } \\
\text { a. DDT } \\
\text { b. Finit } \\
\text { c. Pyrethrum } \\
\text { d. Others } \\
\text { e. No idea }\end{array}$ & $\begin{array}{l}49 \\
1 \\
9 \\
4 \\
28\end{array}$ & $\begin{array}{l}51.57 \\
1.05 \\
9.47 \\
4.21 \\
29.4\end{array}$ \\
\hline $\begin{array}{l}\text { Q8.Ways to prevent Mosquito breeding } \\
\text { a. Cleaning home surroundings } \\
\text { b. Draining stagnant water } \\
\text { c. Clearing bushes around home } \\
\text { d. Others }\end{array}$ & $\begin{array}{l}61 \\
89 \\
37 \\
4\end{array}$ & $\begin{array}{l}64.2 \\
93.6 \\
38.9 \\
4.21\end{array}$ \\
\hline $\begin{array}{l}\text { Q9. What investigations are } \\
\text { done to diagnose malaria? } \\
\text { a. Blood test } \\
\text { b. Urine test } \\
\text { c. Rapid diagnostic tests } \\
\text { d. no idea }\end{array}$ & $\begin{array}{l}78 \\
3 \\
18 \\
4\end{array}$ & $\begin{array}{l}82.1 \\
3.15 \\
18.9 \\
4.21\end{array}$ \\
\hline $\begin{array}{l}\text { Q.10 Symptoms of Malaria } \\
\text { a.Fever } \\
\text { b.Nausea } \\
\text { c. Headache } \\
\text { d.Bodyache } \\
\text { e.Vomitting } \\
\text { f.Shivering }\end{array}$ & $\begin{array}{l}90 \\
70 \\
32 \\
37 \\
22 \\
54\end{array}$ & $\begin{array}{l}94.70 \\
17.90 \\
33.70 \\
38.90 \\
23.20 \\
56.80\end{array}$ \\
\hline
\end{tabular}

towards malaria by stating that it could kill if not treated.
Vol. 5 No. 9 (Sep. 2012)

ISSN: 0974- 6846
Table 2. Modes of transmission of Malaria

\begin{tabular}{|l|c|c|}
\hline \multicolumn{1}{|c|}{ Modes of transmission } & No. & $\%$ \\
\hline Mosquito bite & 91 & 97.80 \\
\hline Drinking dirty water & 11 & 11.60 \\
\hline Food & 3 & 3.15 \\
\hline Blood transfusion & 61 & 64.20 \\
\hline Contact & 19 & 20 \\
\hline Vertical transmission & 27 & 29.50 \\
\hline
\end{tabular}

Table 3. Modes of protection against mosquito bite.

\begin{tabular}{|l|c|c|}
\hline $\begin{array}{c}\text { Modes of protection against } \\
\text { mosquito bite }\end{array}$ & No. & $\%$ \\
\hline Bed nets & 61 & 64.21 \\
\hline Screening of building & 16 & 16.84 \\
\hline Insecticidal sprays & 31 & 32.60 \\
\hline Mosquito coil/Repellant & 65 & 68.40 \\
\hline Use of smoke & 16 & 16.80 \\
\hline Prevention of breeding & 47 & 49.50 \\
\hline Use of fan & 18 & 18.90 \\
\hline Covering body with sheets & 10 & 10.50 \\
\hline Cleaning of house & 46 & 48.40 \\
\hline Others & 7 & 7.40 \\
\hline No idea & 3 & 3.20 \\
\hline
\end{tabular}

Table 4. Self-medication in malaria

\begin{tabular}{|l|c|c|}
\hline \multicolumn{1}{|c|}{ Form of self-medication } & No. & (\%) \\
\hline a. Antipyretics & 3 & 25 \\
\hline b. Antibiotics & 4 & 33.3 \\
\hline c. Antimalarial & 8 & 66.7 \\
\hline d. Others & 0 & 0 \\
\hline
\end{tabular}

Table 5.Source of information for Insecticide treated bed

\begin{tabular}{|l|c|c|}
\multicolumn{3}{|c|}{ Source } \\
\hline a. Mass media & No. & $(\%)$ \\
\hline b. Newspaper/Magazines & 6 & 36.8 \\
\hline c. Health service provider & 3 & 31.5 \\
\hline d. Teachers & 2 & 15.8 \\
\hline e. Relatives and friends & 4 & 10.5 \\
\hline
\end{tabular}

In another study in Bangladesh by Ahmed et al. (2009), a tiny fraction of respondents could accurately state the correct transmission route.

Dirty stagnant water as breeding site for malaria vector was the response of $90(94.7 \%)$ students, in the present study. In a study carried out by Humphrey D. Mazigo et al. (2010), on KAP about malaria and its control in rural NW Tanzania, stagnant water was mentioned by almost two third of respondents to be the main area for mosquito breeding.

Out of total $95,71(74.7 \%)$ respondents in the present study knew Plasmodium as the Malaria Parasite. In another study done in Bangladesh ${ }^{4}$ none of the respondents could state the parasitological cause.

Among the reported symptoms of malaria, this study reported fever to be the most common answer followed by shivering (56.8\%). Headache, high temperature/fever and chills were found to be the three most frequently mentioned signs and symptoms of malaria in a study carried out in Swaziland. Another study conducted in
Popular article

Clndian Society for Education and Environment (iSee)
"KAP on malaria"

http://www.indjst.org
L.R.Kollur et al. Indian J.Sci.Technol. 
Table 6. Source of information for Indoor residual spraying.

\begin{tabular}{|l|c|c|}
\hline \multicolumn{1}{|c|}{ Source } & No. & $(\%)$ \\
\hline a. Mass media & 11 & 34.37 \\
\hline b. Newspaper/Magazines & 8 & 25 \\
\hline c. Health service provider & 10 & 31.25 \\
\hline d. Teachers & 2 & 6.25 \\
\hline e. Relatives and friends & 6 & 18.75 \\
\hline
\end{tabular}

Banladesh by Ahmed et al. (2009) showed that majority of the respondents had mentioned fever (with shivering, at intervals) as the most common symptom of malaria.

In the present study, $41(43.1 \%)$ responded that they Fig. 1. Modes of transmission of Malaria

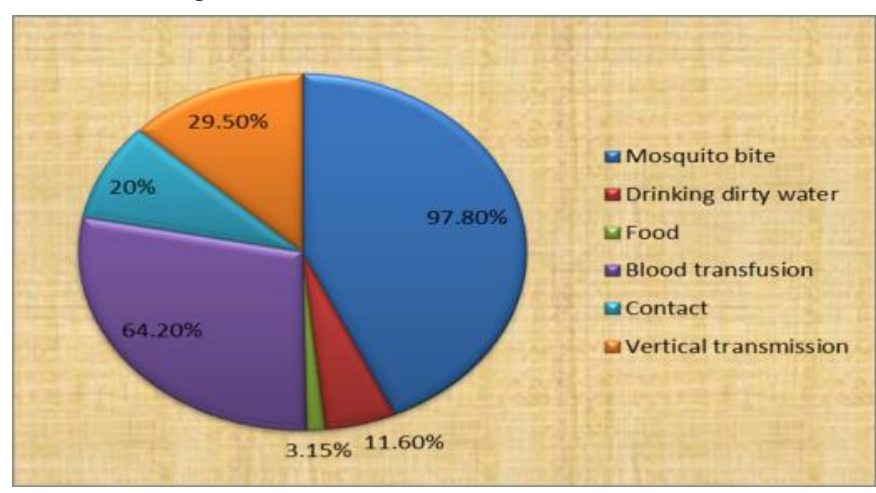

Fig. 2. Modes of protection against mosquito bite.

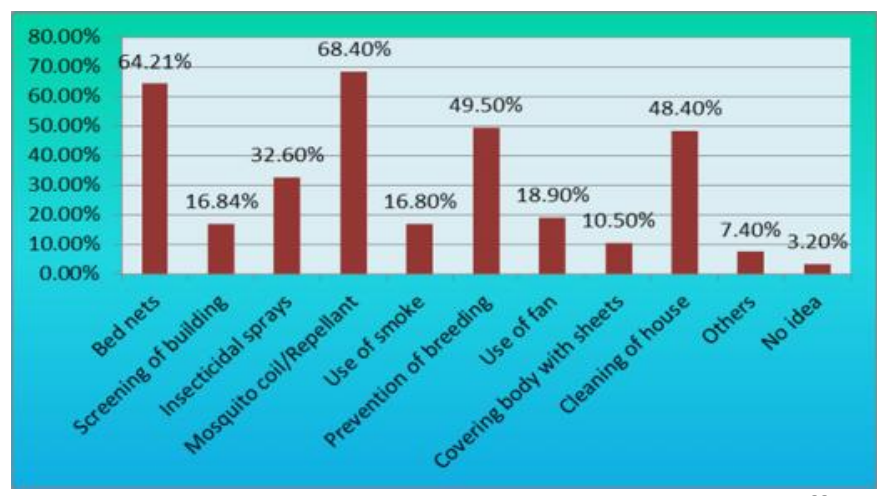

themselves or any one known to them had ever suffered from malaria and investigation to diagnose malaria, according to $78(82.1 \%)$ respondents was blood test followed by Rapid Diagnostic Test (RDT) (18.9\%).

Using coil or repellants in house was found to be most commonly $(68.4 \%)$ used measure to protect from mosquito bite followed by use of mosquito nets $(64.2 \%)$ in the present study. In the study carried out by Hlongwana et al. (2009) in Swaziland with regard to personal protective measures, some participants stated that they use bed nets followed by mosquito coils. Observation regarding personal protection measures to avoid mosquito bite, in the study in Delhi (Tyagi et al., 2005), showed usage of mosquito net as the preferred method followed by usage of insecticides.

In the study done by Hlongwana et al. (2009) in Swaziland majority of the respondents (21.6\%) mentioned spraying to be the preventive measure of choice as against draining of stagnant water (93.6\%) in the present study.

\section{Conclusion}

Study found that knowledge regarding the preventive methods such as insecticide treated nets, indoor residual spraying to be comparatively less as compared to other methods and not many students knew about Rapid Diagnostic Tests.

\section{References}

1. Park K (2011) Textbook of preventive and social medicine. XXI Edn. Jabalpur: Bhanot Publ. pp: 232, 380.

2. Park K (2009) Textbook of preventive and social medicine.XXedn. Jabalpur: Bhanot Publ. pp: 775776.

3. Hlongwana $\mathrm{K}$ et al., (2009) Community knowledge, attitudes and practices (KAP) on malaria in Swaziland: A country earmarked for malaria elimination. Malaria J. pp: 8-29.

4. Ahmed S et al, (2009) Knowledge on the transmission, prevention and treatment of malaria among two endemic populations of Bangladesh and their health-seeking behaviour. Malaria J. 8, 173.

5. Tyagi $P$ et al, (2005) Knowledge, awareness and practices towards malaria in communities of rural, semi-rural and bordering areas of East Delhi (India). J. Vect. Borne Dis. 42, 30-35.

6. Mazigo HD et al, (2010) Knowledge, attitudes, and practices about malaria and its control in rural northwest Tanzania. Malaria Research and Treatment. 